"Przegląd Prawa Konstytucyjnego" Nr $3(15) / 2013$

\title{
Sprawozdanie
}

\section{Seminarium Badaczy Prawa Konstytucyjnego: Wolności i prawa ekonomiczne, socjalne i kulturalne w Polsce i państwach europejskich, Opole, 9-10 kwietnia 2013 r.}

Zainicjowane przez rzeszowskich konstytucjonalistów, organizowane regularnie od 2010 r., Seminaria Badaczy Prawa Konstytucyjnego trwale wpisały się w kalendarz konferencyjny młodego pokolenia przedstawicieli nauki prawa konstytucyjnego i politologii. Spotkania te dochodzą do skutku dzięki staraniom komitetu organizacyjnego reprezentowanego przez wszystkie większe ośrodki akademickie w Polsce. Szczególna rola i trud organizacji oraz koordynacji przedsięwzięcia przypada jednej osobie, którą zwykle jest pracownik „miejscowej” uczelni wyższej.

Odbywające się cyklicznie wiosną i jesienią seminaria służą realizacji wielu celów istotnych z punktu widzenia polskiego środowiska uniwersyteckiego. Stanowią one swego rodzaju platformę naukową oraz integracyjną, umożliwiając swobodną wymianę myśli, zaprezentowanie poglądów naukowych, skonfrontowanie tez badawczych czy omówienie głównych nurtów zmian szeroko pojętego prawa państwowego zarówno w Polsce, jak i w innych państwach. Pokłosiem Seminariów są interesujące artykuły naukowe publikowane na łamach prężnie rozwijającego się periodyka prawniczego „Przeglądu Prawa Konstytucyjnego".

Kontynuując tę niespełna czteroletnią tradycję, w dniach 9-10 kwietnia 2013 r. w Opolu odbyło się kolejne, VII Seminarium Badaczy Prawa Konstytucyjnego. Wyrazy wdzięczności i uznania za znakomitą organizację tegorocznego spotkania należą się jego organizatorce - dr Annie Frankiewicz z Uniwersytetu Opolskiego. 
Po przyjeździe, zakwaterowaniu i wspólnym obiedzie rozpoczęły się obrady. Zostały one podzielone na dwie sesje, z których pierwsza odbyła się 9 kwietnia, a druga 10 kwietnia. Pierwszej sesji przewodniczyła dr Agnieszka Bień-Kacała (Uniwersytet Mikołaja Kopernika). Merytoryczną część obrad rozpoczęło wystąpienie dr Anny Kosińskiej (Katolicki Uniwersytet Lubelski) na temat: Szczególny charakter praw kulturalnych i ich miejsce w Konstytucji RP - próba charakterystyki i kwalifikacji. Dokonując analizy konstytucyjnych regulacji dotyczących praw kulturalnych, Autorka podjęła próbę ich charakterystyki i kwalifikacji. Główna teza referatu opiera się na założeniu, zgodnie z którym kultura jako wartość o szczególnym znaczeniu ma istotny wpływ na osobowy rozwój każdego człowieka. Z tego względu prawa kulturalne stanowią ważny element w życiu współczesnych społeczeństw. Definiując pojęcie praw kulturalnych, prelegentka przedstawiła różne desygnaty terminu „kultura”. Następnie dokonała analizy regulacji określonej w art. 5, 6 i 73 Konstytucji. W ramach wniosków de lege ferenda dr Anna Kosińska dostrzegła potrzebę zmiany rozdziału II Konstytucji poprzez przepisy gwarantujące prawo dostępu do dóbr kultury.

Następny referat zatytułowany Reprywatyzacja dóbr kultury w Polsce doświadczenia $i$ otwarte problemy wygłosiła dr Sylwia Jarosz-Żukowska (Uniwersytet Wrocławski). Prelegentka poruszyła istotny problem, czy dzieła sztuki, kolekcje biblioteczne i archiwalne należy zwrócić w całości dawnym właścicielom, czy powinny one nadal znajdować się w zbiorach publicznych, do których możliwy będzie bezpośredni dostęp, w tym także dla badań naukowych. Rozważając to zagadnienie, prelegentka przychyliła się do poglądu, że przenoszenie na prywatnych właścicieli obowiązków władz publicznych wynikających z art. 73 Konstytucji oznaczałoby nadawanie temu przepisowi skutku horyzontalnego. Natomiast na gruncie art. 6 Konstytucji dostęp do dóbr kultury należy rozumieć jako stworzenie możliwości kontaktu z nimi wszystkim zainteresowanym, aczkolwiek dostęp ten niekoniecznie musi mieć charakter bezpośredni. Następnie prelegentka poruszyła zagadnienie trwającej w Polsce od ponad 20 lat tzw. reprywatyzacji sądowej. Powołując się na obszerne orzecznictwo sądowe, wyjaśniła, że stanowi ona realny sposób odzyskania utraconej własności, w tym dóbr kultury. W zakończeniu jako rozwiązanie optymalne powiązane ze zwrotem własności prelegentka zaproponowała konstrukcję przechowania (depozytu) - polega- 
jącą na eksploatacji przez muzea publiczne oddanego im na przechowanie obiektu stanowiące własność prywatną.

Jako trzecia wystąpiła dr hab. Anna Młynarska-Sobaczewska (Uniwersytet Łódzki), która wygłosiła referat pt.: Prawo do kultury, prawa kulturalne prawne gwarancje kultury w życiu jednostek i zbiorowości. W toku pogłębionej refleksji nad tytułowym zagadnieniem Autorka podjęła próbę udzielenia odpowiedzi na pytanie, czy prawu do udziału w życiu kulturalnym można przypisać strukturę normatywną $\mathrm{i}$ - jeśli tak - jak kształtuje ona zakres, treść oraz obowiązki podmiotów zobowiązanych do jego ochrony w obowiązujących aktach prawnych o zasięgu uniwersalnym, europejskim oraz w porządkach krajowych. Referat miał charakter wielowątkowy, w szerokim zakresie wykorzystujący analizę komparatystyczną. Autorka podjęła wiele istotnych problemów, m.in. kwestię uniwersalnego systemu ochrony dóbr kultury i prawa do udziału w życiu kulturalnym, zagadnienie systemu ochrony w europejskim porządku prawnym w tym działalność prawotwórczą Unii Europejskiej czy kwestię normatywnego kształtu prawa do kultury w konstytucjach państw europejskich. Poddała również analizie orzecznictwo Europejskiego Trybunału Praw Człowieka w zakresie prawa do udziału w życiu kulturalnym oraz praw pokrewnych.

Pierwszą sesję zakończyło wystąpienie dr Moniki Urbaniak (Uniwersytet Medyczny w Poznaniu) pt.: Konstytucyjne prawo do ochrony zdrowia a jego ustawowa realizacja $w$ prawie polskim. Prelegentka poddała obszernej analizie art. 68 Konstytucji stanowiący ustrojową podstawę prawa do ochrony zdrowia. W toku referatu poruszyła problem finansowania świadczeń z zakresu ochrony zdrowia, prowadzący - w warunkach niedoboru środków finansowych - do wysuwania postulatów zwiększania wydatków na opiekę zdrowotną. Szukając remedium na tę sytuację, prelegentka przychyliła się do postulatu wprowadzenia systemu dodatkowych ubezpieczeń prywatnych oraz mechanizmów współpłacenia za określone świadczenia zdrowotne, co mogłoby przyczynić się do pełniejszej realizacji prawa do ochrony zdrowia i prawidłowego korzystania ze świadczeń zdrowotnych.

Po wystąpieniach prelegentów rozpoczęła się burzliwa dyskusja związana z tematyką wygłaszanych referatów. Zaangażowali się w nią niemal wszyscy uczestnicy seminarium. Wymaga odnotowania, że poszczególne problemy były również dyskutowane na bieżąco w toku obrad, po każdym z wystąpień. 
Tradycyjnym uwieńczeniem pierwszego dnia obrad była uroczysta kolacja, na której zgromadzili się i odpoczywali w wyśmienitej atmosferze wszyscy uczestnicy Seminarium. Podczas dyskusji przy kolacji dokonano wstępnego ustalenia tematyki kolejnego seminarium, która ma dotyczyć zagadnień ustrojów państw mniej znanych, zwłaszcza spoza Europy, oraz możliwości implementowania funkcjonujących w nich rozwiązań do polskiego systemu ustrojowego. Komitet organizacyjny Seminariów Badaczy Prawa Konstytucyjnego zaproponował, aby organizatorami kolejnego spotkania naukowego byli przedstawiciele środowiska konstytucjonalistów Uniwersytetu Jagiellońskiego. Pomysł ten spotkał się z aprobatą zgromadzonych osób, toteż ustalono, że VIII Seminarium odbędzie się w Krakowie.

W drugim dniu Seminarium obradom przewodniczyła dr Joanna Juchniewicz (Uniwersytet Warmińsko-Mazurski). Jako pierwszy swój referat wygłosił dr Ryszard Balicki (Uniwersytet Wrocławski). Swoje wystąpienie zatytułowane: Prawa człowieka w czasie kryzysu prelegent rozpoczął od zagadnienia tzw. praw II generacji, do których - obok praw ekonomicznych i socjalnych - należą również prawa kulturalne. Współcześnie prawa te chronione są przede wszystkim Międzynarodowym Paktem Praw Gospodarczych, Społecznych i Kulturalnych. Rozwojowi, poszanowaniu i ochronie tych praw nie sprzyja nękający m.in. Polskę od kilku lat kryzys gospodarczy. Zmusza on państwa nim dotknięte do aktywności nastawionej przede wszystkim na zabezpieczenie interesów przedsiębiorców, co ujemnie wpływa na poszanowanie praw kulturalnych. Nie jest to jednak pozytywna tendencja, bowiem pokonanie kryzysu nie będzie możliwe bez odwołania się do praw kulturalnych i zasad etycznych. W podsumowaniu referatu jako remedium na zauważone niedostatki w poszanowaniu praw kulturalnych dr Balicki zaproponował powrót do wartości oraz prowadzenie polityki gospodarczej w oparciu o przejrzyste zasady oparte na etyce.

Następny referat pt.: O potrzebie konstytucjonalizacji praw społecznych wygłosił dr Janusz Karp (Uniwersytet Jagielloński). W swym wystąpieniu prelegent dokonał charakterystyki określonych w tytule praw społecznych jako konstytucyjnych uprawnień jednostki. Ukazując ważkość i złożoność tego zagadnienia, autor podjął próbę wykazania, że nie wszystkie prawa należące do tej kategorii mają umocowanie konstytucyjne. Niektóre tego typu uprawnienia funkcjonują bowiem bez stosownego ustrojowego zabezpie- 
czenia, mając podstawę w ustawodawstwie zwykłym. Stanowi to asumpt do podjęcia dalszej, pogłębionej dyskusji w gremiach naukowych oraz sformułowania w tym zakresie ewentualnych wniosków de lege ferenda.

Trzecią prelegentką w drugim dniu obrad była dr Małgorzata Myśliwiec (Uniwersytet Śląski) z referatem pt.: Ślōnskŏ godka - przaśny folklor czy ustawowo uznany język regionalny? Zasadniczy problem, jaki rozważała prelegentka, sprowadzał się do pytania, dlaczego władze Rzeczypospolitej Polskiej nie chcą uznania za język regionalny śląskiego etnolektu, nazywanego w regionie „ślōnskom godkom”. W toku wywodu zostały zaprezentowane antecedencje problemu oraz starania legislacyjne śląskich posłów i organizacji dbających o zachowanie regionalnego języka w tym zakresie, a także próba postawienia prognozy, dotyczącej owego procesu. Rozważając kilka możliwości rozwiązania podjętego zagadnienia, dr Myśliwiec opowiedziała się za ustawowym uznaniem śląskiego etnolektu za język regionalny. Byłaby to decyzja satysfakcjonująca zapewne znaczną część mieszkańców regionu, deklarujących przynależność do mniejszości śląskiej. Ponadto przemawia za tym także znaczny stopień zaawansowania prac nad kodyfikacją „ślōnskiej godki” i powstawania kolejnych dzieł tzw. kultury wysokiej (np. wyreżyserowania sztuki „Cholonek” według Janoscha czy „Piątej strony świata” według Kutza).

Podobnie, jak w pierwszym dniu obrad, także po drugiej sesji uczestnicy dyskutowali na temat zagadnień związanych z tematyką seminarium. Niepowtarzalna, serdeczna atmosfera seminarium, potęgowana urokami miejsca, w którym się ono odbywało, oraz osób biorących w nim udział, nastrój panujący podczas obrad, a także ich wysoki merytoryczny poziom spowodowały, że spotkanie zorganizowane w ramach VII Seminarium Badaczy Prawa Konstytucyjnego z pewnością będzie wydarzeniem dobrze wspominanym przez jego uczestników.

Bartłomiej Opaliński Uczelnia Łazarskiego w Warszawie 